\title{
Effect of Agility Training Towards Soccer Dribbling Skills
}

\author{
John Arwandi ${ }^{1 *} \&$ Mhd Firdaus $^{2}$ \\ ${ }^{1,2}$ Dep. of Coaching, Faculty of Sport Science, Universitas Negeri Padang, Indonesia \\ *Corresponding author. Email: johnarwandi@fik.unp.ac.id
}

\begin{abstract}
The problem in this research is the provision of agility training in improving soccer dribbling skills. This study aims to determine the effect of agility training on dribbling skills on SSB SerojaJambu Air Bukittinggi players. The method used in this research is an experiment. Sampling using a purposive sampling technique amounting to 32 people. The variables of this research are the form of agility training (X) and dribbling skills (Y). This research was conducted for 6 weeks (18 meetings), in 1 week the training was held 3 times. The research instrument used was to use the skills to test dribbling as a test in the pretest and posttest. The results of the study found that: (1) the average skills of the initial test (pretest) 10.76 seconds, (2) the average skills of the final test (posttest) 9.88 seconds. From the results obtained at the pretest and posttest, it can be concluded that there is an effect of agility training on dribbling skills on SSB SerojaJambu Air Bukittinggi players. The application of agility training forms to improve soccer dribbling skills.
\end{abstract}

Keywords: Agility Training, Soccer Dribbling Skills

\section{INTRODUCTION}

The development of soccer began with associations in schools and universities in England. Outside of schools and universities, soccer is growing rapidly but has not used the same rules with each other. On October 26, 1863, these associations outside schools and universities established a body called "The Soccer Association". So it can be said that modern soccer originated in England. And on May 21, 1904, in France, the soccer federation stood by the name "FederationInternationale De Football Association".Sucipto (2000) defines "soccer is a team game consisting of eleven players, and one of them is a goalkeeper." Furthermore,Roji (2004) explains "soccer is carried out by two teams, each eleven. In soccer, round balls are used and are led by a referee and two line judges.

Soccer is a sport that is played by two teams of eleven players, including the goalkeeper in each team, with the aim of putting the ball in the opponent's goal and keeping the goal in itself, there are several benefits in doing this soccer game including the brain, strengthen mentally, train discipline, improve physical health, outreach and teamwork. then each player is required to have various skills, techniques, and tactics, in addition to excellent physical and mental condition. According to the UNP FIK Soccer Teaching Team (2006) "all activities in soccer are carried out with movements, both movements carried out without the ball such as, running, jumping, seizing the ball, and or movement with the ball such as passing, control, dribbling, shooting dan heading".

The ultimate goal of a soccer game is victory. This requires a variety of techniques and good strategies to create a goal against the opponent. In soccer, the connection between one component and the other is very important, meaning that to be able to play soccer well, one must also be able to master good basic technical skills. One of the basic techniques in playing soccer is dribbling or dribbling. Dribbling is a technique to move the ball using your feet from one place to another to achieve the goal of holding a counterattack, passing the opponent, luring the opponent, adjusting the tempo of the game and scoring goals against the opponent's goal effectively and efficiently.

In essence, each player is required to be able to do dribbling. Djezed (1999) "suggests that to obtain the desired dribbling results in accordance with their needs in play is influenced by talent and willingness factors, leg muscle strength, speed, flexibility, body balance, and agility".Among these factors, the agility factor is one of the factors that need attention to improving dribbling skills. Agility is the ability to change direction quickly without the body losing balance in doing so. Agility willa big influence on dribbling techniques not only carrying the ball down the ground and straight ahead but facing an opponent who is quite close and 
close. With high agility, the player can dribble past and free himself from the opponent's escort with the movement to change direction as quickly as possible. Thus it can be expected that soccer players who have good agility will help these players to dribble well so that the desired soccer game idea can be achieved properly.

To improve the ability of agility by choosing the right method and form of training, it really needs to get attention. Many methods or forms of training that can be used to improve the agility of the players. Agus (2012) suggests several forms of agility training that can be used, namely, "reacting agility exercises, three corner drill, hexagon drill, wind sprint, starting stoping run, shuttle run, and zig-zag run". In addition, there are also other forms of training that can increase agility such as squat-trust, dodging run, boomerang run, and others.

Thus, researchers are interested in conducting research on the Effect of the Form of Agility Training on the Dribbling Ability of SSB SerojaJambu Air Bukittinggi. It is expected that the results of this study can produce a conclusion that can be guided by the improvement of the achievements of the SSB SerojaJambu Air Bukittinggi players. Training according to Syafrudin (1996) describes a process of working or processing training materials such as movement skills in the form of repetitive implementation and through a variety of sequences. The above understanding can be understood by us that exercise is a process of activities carried out repeatedly and has diverse demands. Bompa in Bafirman (2010) says that "exercise is a physical activity carried out systematically over a long period of time, progressively enhanced and individualized that leads to the physiological and psychological functions of human beings to achieve their intended goals".

\section{RESEARCH METHODS}

This type of research is an experiment, where this study compares the effect of one independent variable on a dependent variable. The independent variable $(\mathrm{X})$ referred to in this study is a form of agility exercise. While the dependent variable (Y) is dribbling ability.The research design used was One Group Pretest - Postest Design. This study provides treatment of one independent variable. Which later the sample will be given treatment in the form of agility training.

This study aims to see whether there is an effect of the form of agility training on the dribbling ability of SSB SerojaJambu Air Bukittinggi players which the writer took directly. Because this study does not use a control group, this research can be classified as quasiexperimental research. This research was carried out in the KayuGadihJambu Air Bukittinggi field, where this field was the field used by SSB SerojaJambu Air
Bukittinggi during the exercise. When the study was conducted March 28, 2019, to May 4, 2019. Which exercise was held 3 times a week ie on Wednesday, Friday and Sunday.

The sample was taken based on certain criteria, namely according to the age level phase and the limited time and energy, then the samples in this study were athletes in the development phase of the U14 - U17 soccer game, amounting to 32 people.The data needed in this study is the ability of dribbling performed by SSB SerojaJambu Air Bukittinggi players. Data analysis techniques in this study used the t-test. Before the t-test is performed first, the analysis requirements test is carried out, namely the homogeneity and normality test.

\section{RESULTS AND DISCUSSION}

The first retrieval data (pretest), for dribbling ability, has a higher time record than the second retrieval data (posttest). This shows that in the posttest, SSB SerojaJambu Air Bukittinggi players improved their dribbling ability which was influenced by the form of agility training they got, making notes of dribbling time on SSB SerojaJambu Air Bukittinggi players getting better. Evidently, the average ability of dribbling SSB SerojaJambu Air Bukittinggi players at the pretest was 10.76 seconds, while at the posttest was 8.09 seconds.

After the pretest or initial test, the researcher carries out or provides a form of agility exercise. Based on the results of the final test, it can be seen that this form of agility training has a significant effect on improving the ability to dribble in SSB SerojaJambu Air Bukittinggi players. Thus it can be concluded, on the first data collection (pretest) for the test of dribbling ability, it is known that the ability of SSB SerojaJambu Air Bukittinggi players tends to be low, while in the second taking (posttest) tends to be higher. After obtaining the pretest data, SSB SerojaJambu Air Bukittinggi players were treated in the form of an exercise program approach in the form of agility training with the aim to form basic techniques in dribbling skills, by providing an appropriate portion of playing practice or games aimed at practicing dribbling skills. on the SSB SerojaJambu Air Bukittinggi player.

The hypothesis of this study was tested using the $\mathrm{t}$-test analysis. Before analyzing the t-test, the normality and homogeneity tests are carried out to determine whether the data are homogeneous and come from populations that are normally distributed or not. Data normality test was analyzed with Shapiro wick test statistics, with a significant level that is used as a basis for rejecting or accepting a normal decision whether or not a data distribution is 0.05 . The results of the normality test distribution for pre-test and post-test give 
results that for pre-test dribbling ability normally distributed with sig. greater than 0.05 which is equal to 0.1534 , while for the post-test gives the result that the ability of dribbling is normally distributed with a sig value. greater than 0.05 which is equal to 0.1221 . This means that the variable form of agility training for soccer players is normally distributed because the significance value is $>0.05$.

The next prerequisite to fulfill the analysis is to test the homogeneity of the data variance. The homogeneity test for variance is calculated using the variance test, the test criteria if the significance of $>0.05$ data is stated to originate from a homogeneous sample, conversely, if the significance $<0.05$ data is stated to originate from homogeneous data. Based on homogeneity test data obtained results as listed in the table below. Based on table 6 , it turns out that Fount (1.04) <Ftable (1.84), it can be concluded that the two variances are homogeneous.

Based on the results of the study showed that there is a significant influence between the form of agility training on the ability of soccer dribbling on SSB SerojaJambu Air Bukittinggi players. Variable forms of agility training affect the ability of soccer dribbling on SSB SerojaJambu Air Bukittinggi players. This illustrates that this form of agility training can be used as a training method to improve dribbling skills. In conducting research, the first time data is taken is called pre-test. This pre-test aims to see the initial ability of the player's ball dribbling. From the pre-test data, the results of the dribbling ability of the SSB SerojaJambu Air Bukittinggi players with an average of 10.76 seconds and after being given the form of agility training will be carried out post-test to return to see the dribbling results of the SSB SerojaJambu Air Bukittinggi players with an average post-test value 9.87 seconds. This means that the form of agility training can improve the dribbling ability of SSB players in Jambu Air Bukittinggi.

In an effort to improve the dribbling ability of SSB SerojaJambu Air Bukittinggi players, they were given several forms of agility training, namely reacting agility exercises, Squat Trust,Shuttle Run,ZigzagRun,WindSprint,Dotging Run, TreeCornel Drill, Hexagon Drill, and boomerang Run.Agility is the ability to change positions and directions quickly without losing balance. Harsono (1988) argues that agility is the ability to change the direction and position of the body precisely when it is moving, without losing balance and awareness of body position. By doing this form of agility training, the player can position their body correctly, maintain balance and have the ability to perform varied dribbling movements.

Agility is a movement ability that must be possessed by a soccer player because with high agility the player can save energy in a game. With good agility, then a player will more easily master the basic techniques in soccer because most of the basic techniques in soccer can be done well if the player has a good level of agility. Besides that, having good agility will minimize injury. Dribbling while running past an opposing opponent where events on the field do not rule out the possibility that a player can be blocked by two or even three players. All types of good dribbling consist of several components. These components include sudden changes in speed and direction, body and leg tricks, and tight ball control.

This is in accordance with the opinion of Suharno (1985) that the use of agility is to coordinate multiple movements or stimulants, facilitate the adoption of high techniques, efficient movements, effective and facilitate orientation towards opponents and the environment. Correspondingly, Ilmi (2019) said that the importance of agility or the ability of athletes to change the movement as quickly as possible in dribbling, because athletes do not always move the ball from one area to another by running forward, sometimes they have to reverse direction back to avoid the opponent, or move left and right to pass the opposing player. Situations and conditions that occur like these soccer athletes must have good agility.

Then Saputra in his journal (2019) said that Agility is one of the factors that affect the ability of a player, when players dribbling players are required to turn around in a short time without losing balance to overcome the spoils of opponents, players who have a level of agility the good tend to have smooth movement coordination.This is consistent with the opinion of Pratama in his journal (2018) saying that Agility is very important for soccer games because agility is very closely related in passing through opponents quickly and flexible so that agility is very well applied in various circles for training wherein the case can be attributed to the flexibility of the game of soccer, especially in achievement athletes.

Dribbling itself is one of the basic techniques that are very necessary in soccer. Dribbling is a player's ability to control the ball when running. This means that by using dribbling a player is able to create opportunities in an attempt to score the opponent's kegawang goals. Of all the forms of agility training provided, all of them aim to improve the agility of players. Because to be able to do good dribbling the player must have good agility too. So that players are required to have good agility so that they can do dribbling properly. All forms of training provided, all of which provide positive results to increase dribbling skills. If a player can dribbling the ball well, this will be able to help his movement so that the opponent is 
difficult to read the direction of movement and difficulty in seizing the ball. But on the contrary, if an athlete cannot dribbling the ball properly, then the movement of the ball made will be easy to guess in the direction so that the opponent will easily grab the ball.

As Gunawan explained in his journal (201) that there is a significant relationship between agility and the ability to dribbling the ball. Correspondingly, Jayadi in his journal (2018) said that agility training had a real influence on dribbling skills. In addition, Utama in his journal (201) said that agility training had a significant influence in improving dribbling skills. Then Mappaompo in his journal (2012) said that there was a significant relationship of agility with dribbling skills in soccer games. This is consistent with the opinion of Fahrizal in his journal (2016) that there is a relationship of agility to the ability to dribble to soccer players where the greater the agility of soccer players the greater the ability to dribble the soccer player.

Thus it can be concluded that the form of agility training can have a significant influence on the ability of basic dribbling techniques. The results showed that there was a significant effect of the form of agility training on the ability of dribbling SSB SerojaJambu Air with evidence. This means that the form of agility training can influence the ability to dribble soccer players. Therefore, a form of agility training must be given to SSB SerojaJambu Air Bukittinggi players to improve the soccer player's dribbling ability.

\section{CONCLUSIONS AND SUGGESTIONS}

\section{A. Conclusions}

Based on the results of research and hypothesis testing, it can be concluded that there is an effect of the form of agility training on the dribbling ability of SSB Seroja Jambu Air Bukittinggi players.

\section{REFERENCES}

[1] Agus, Apri (2012). Olahraga Kebugaran Jasmani. Padang. FIK UNP Padang.

[2] Arikunto, Suharsimi. 1997. Prosedur Penelitian Suatu Pendekatan Praktek. Jakarta: Rineka Cipta.

[3] Daryanto, Zusyah Porja. 2015. "pengaruh latihan kelincahan terhadap kemampuan menggiring bola".Jurnal Pendidikan Olahraga. 4(2). Diaksespada 22 Februari 2019.

[4] Djezed Zulfar dan Darwis, Ratinus. 1985. Buku pelajaran sepakbola. Padang: FPOKIKIP Padang
[5] Kemampuan Mengiring pada Pemain Sepakbola GDP Sidoarjo U-15 " Jurnal Kesehatan Olahraga. 6(2). Diakses pada22 Februari 2019.

[6] Harsono.1988. Coaching dan Aspek-Aspek Psikologi Dalam Coaching. Jakarta: Depdikbud, Dirjen Dikti P2LPTK.

[7] Hasan, MuhSaid. 2014. "Hubungan Kekuatan Otot Tungkai dan Kelincahan dengan Kemampuan Mengiring Bola dalam Permainan Sepakbola pada Siswa SMP Negeri Satu Sinjai Utara”. Jurnal Penelitian Pendidikan. 6 (2). Diakses pada 22 Februari 2019.

[8] Ilmi, Miftahul, \& Yanuar Kiram. 2019. "Hubungan Koordinasi Mata Kaki Dan Kelincahan Dengan Kemampuan Dribbling Pemain Sepakbola Di Sekolah Sepakbola (SSB Excellent Kota Batusangkar)". Jurnal Patriot. 2(2). Diakses pada 30 Juli2019.

[9] Jayadi, Wahyu, Anto Sukanto \& Hasbunallah. 2015. "Latihan Kelincahan dan Keterampilan Menggiring Bola Pada Permainan Sepakbola". Jurnal Penelitian Pendidikan Insani. 18 (2). Diakses pada30 Juli 2019.

[10] Mappaompo, Muhammad Adam. 2012. "Hubungan Koordinasi Mata Kaki, Keseimbangan, dan Kelincahan dengan keterampilan Menggiring Bola dalam Pernainan Sepakbola Tim Gelora Kabupaten Sinjai". Jurnal ILARA. 3(2). Diakses pada 22 Februari 2019.

[11] Pratama,Yogi Adam, Anin Lukatana \& Cecep Sudijo. 2018. "Pengaruh Latihan Kelincahan Terhadap Keterampilan Dribbling Bola Pada Pemain Sepakbola. Jurnal Sportive. 1 (1). Diakses pada30 Juli 2019

[12] Saputra, Adriyan \& Ronni Yennes. 2015. "Hubungan Kelincahan Dan Kecepatan Dengan Kemampuan Dribbling Pemain Sekolah Sepakbola. Jurnal Patriot.1 (1). Diakses pada 30 Juli 2019

[13] Soekatamsi (1992). Permainan bola besar I (sepakbola). Jakarta: Depdikbud

[14] Suharno. 1993. Ilmu Kepelatihan Olahraga. Yogyakarta:F POKIKIP.

[15] Tim Pengajar Sepakbola.2003. Buku Ajar Sepakbola. Padang:FIK UNP.

[16] ---------. 2006. Buku Ajar Sepakbola.Padang: FIKUNP.

[17] Utama, Andhi Zakariya, Eko Hariyanto \& I Nengah Sudjana. 2015. "Pengaruh Latihan kelincahan dan Kelentukan Terhadap Keterampilan Dribbling Sepakbola SSBPAS-ITN Kabupaten Malang. Jurnal Pendidikan Jasmani. 25 (1) 